\section{Long-term Effects of Peach Production Systems for Standard and Pillar Growth Types on Yield and Economic Parameters}

\author{
D.M. Glenn ${ }^{1}$, T. Tworkoski, R. Scorza, and S.S. Miller
}

AdDITIONAL INDEX WORDs. fruit, sod management, tall fescue, Festuca arundinaceae, vegetation-free area, tree vigor, irrigation, Prunus persica

SuMMARY. The lack of dwarfing rootstocks for peach has led to cultural and genetic approaches that reduce tree size and vegetative growth to establish high-density plantings. The objectives of the study were to evaluate the interactions of pruning strategies, groundcover management, tree densities, and peach (Prunus persica) architecture combined in eight peach production systems on components of yield and economic value. The use of sod management reduced pruning time and costs, but the reduction of crop load reduced net return. High-density plantings in large vegetation-free areas (VFAs) had greater economic return than low-density plantings.

$\mathrm{T}$ The lack of dwarfing rootstocks for peach (Bassi et al., 1994; Grossman and DeJong, 1998) has led to cultural approaches that reduce tree size and vegetative growth to establish high-density plantings. Water management through irrigation (Chalmers et al., 1981) or groundcover competition (Glenn and Welker, 1996; Glenn et al., 1996) has been the two most thoroughly investigated approaches to limiting vegetative growth. In the eastern United States and other humid and semihumid peach-producing areas, irrigation management has not been as useful an approach as it has been in arid and semiarid regions because of natural rainfall (Boland et al., 1994; Naor, 2006; Ran et al., 1992). Groundcover management and the establishment of sod and other herbaceous species beneath or near the tree have been evaluated in several long-term studies for peach production (Glenn and Newell, 2008; Glenn and Welker, 1996; Glenn et al., 1996). Based on the sod management studies, the cultural factor limiting peach yield appears to be the ability to maintain high crop loads (Tworkoski and Glenn,

\footnotetext{
United States Department of Agriculture, Agricultural Research Service, Appalachian Fruit Research Station, 2217 Wiltshire Road, Kearneysville, WV 25430-2771

Mention of trade names or commercial products in this article is solely for the purpose of providing specific information and does not imply recommendation or endorsement by the U.S. Department of Agriculture. USDA is an equal opportunity provider and employer.

${ }^{1}$ Corresponding author. E-mail: michael.glenn@ars.usda.
} gov.
2001, 2010; Glenn and Newell, 2008). Naor (2006) similarly cautions that long-term use of deficit irrigation has the potential to reduce tree productivity because of reduced canopy development. Studies indicate that fruit size is not consistently reduced by sod or groundcover competition (Glenn and Welker, 1996; Glenn and Newell, 2008) but crop load is reduced (Glenn and Newell, 2008; Tworkoski and Glenn, 2010), subsequently reducing overall yield. A third approach to develop high-density peach production systems is the use of peach cultivars with tree architectures that suit high planting densities. Scorza $(1984,1988)$ and Scorza et al. (2006) have developed columnar growth habit "pillar" peaches that are suitable for highdensity peach production. Miller and Scorza (2002) evaluated training strategies for pillar peach and concluded that a multiple leader (ML) with minimal early pruning was the most effective in developing a productive tree. In a continuation of their work, Miller and Scorza (2010) demonstrated that the pillar growth type significantly reduced pruning time compared with standard tree architecture at high density. The objectives of the study were to evaluate the interactions of pruning strategies, groundcover management, tree densities, and peach architecture combined in eight peach production systems on components of yield and economic value.

\section{Materials and methods}

'Loring' peach on Lovell seedling rootstock and pillar growth habit selection KV930465, a sibling of 'Crimson Rocket' (Scorza, 2004), were planted in Spring 1999. Branched 1year-old nursery 'Loring' trees were cut back to a 3 -ft height after planting; pillar trees were not cut back and allowed to develop MLs. Trees were planted in north-south oriented rows spaced $18 \mathrm{ft}$ apart. 'Loring' trees were planted at either 5 - or 15 -ft spacing within the row. All pillar trees were spaced at $5 \mathrm{ft}$ within rows. A randomized complete split-plot design with six replications was used. Each plot was 8$\mathrm{ft}$ wide and contained four trees with a guard tree between plots in each row. The main plot was the width of the VFA ( 2 or $8 \mathrm{ft})$. The split plot was the cultivar-pruning system. Four pruning treatments were imposed in relation to the in-row spacing. 1) 'Loring' at 15-ft spacing were trained to the traditional "open-center" system (OC). In this system, vigorous suckers were removed and the primary structural limbs were forced outward using thinning type "bench" cuts. This system represented the traditional peach production system. 2) 'Loring' at 5-ft spacing was trained with either a "minimally pruned central leader" system (CL) in which only four to eight of the largest branches were removed annually or 3 ) a more detailed "Y-shaped" tree architecture $(\mathrm{Y})$ with two to four permanent scaffolds and no CL. All 'Loring' trees were maintained at 8 -ft height. 4) Pillar

\begin{tabular}{llll}
\hline $\begin{array}{l}\text { Units } \\
\text { To convert U.S. to SI, } \\
\text { multiply by }\end{array}$ & U.S. unit & SI unit & $\begin{array}{l}\text { To convert SI to U.S., } \\
\text { multiply by }\end{array}$ \\
\hline 0.4047 & acre(s) & $\mathrm{ha}$ & 2.4711 \\
0.3048 & $\mathrm{ft}$ & $\mathrm{m}$ & 3.2808 \\
3.7854 & gal & $\mathrm{L}$ & 0.2642 \\
2.54 & inch(es) & $\mathrm{cm}$ & 0.3937 \\
6.4516 & inch & $\mathrm{cm}^{2}$ & 0.1550 \\
0.4536 & $\mathrm{lb}$ & $\mathrm{kg}$ & 2.2046 \\
1.1209 & $\mathrm{lb} / \mathrm{acre}$ & $\mathrm{kg} \cdot \mathrm{ha}^{-1}$ & 0.8922 \\
0.1198 & $\mathrm{lb} / \mathrm{gal}$ & $\mathrm{kg} \cdot \mathrm{L}^{-1}$ & 8.3454 \\
28.3495 & $\mathrm{oz}$ & $\mathrm{g}$ & 0.0353
\end{tabular}


trees were pruned to maintain their natural upright stature with one to three primary leaders in a "multiple leader" system (Miller and Scorza, $2002,2010)$. Since the pillar tree is developed for high-density planting, it was only planted at 5 -ft spacing. All trees were pruned from the ground. Pruning cuts on the pillar trees required a pole pruner above $8 \mathrm{ft}$ and trees were maintained at 12 - $\mathrm{ft}$ height in the dormant season. Data were collected from the center two trees. All trees were pruned in the dormant season each year by the same individual for the entire study. When pruning the trees, no attempt was made to keep the two treatment canopies of similar dimensions, i.e., the trees were allowed to grow outward until they filled the allotted space. Hand thinning commenced after June drop. Final fruit spacing was 2 to 6 inches along the shoot. Sod of 'Kentucky-31' (K-31) tall fescue (Festuca arundinacea) was established in the drive middle. Following planting, the tree row strip was maintained with either an 8-ft-wide or 2 -ftwide VFA. Analysis of the randomized split-plot design of the study resulted in two- and three-way interactions by year and treatment requiring analysis of the eight individual treatment combinations with no pooling of main- or split-plot effects. Consequently, eight production systems were evaluated with these combinations of cultivar, tree spacing, pruning, and VFA (Table 1).

All fruit were harvested at either one or two dates in August in all years. There were no severe frosts that eliminated cropping but some frost damage did occur in 2 years. The pillar peach was harvested 7 to $10 \mathrm{~d}$ before 'Loring'. The 8-ft-wide VFA received $300 \mathrm{lb} /$ acre of $10 \mathrm{~N}-4.4 \mathrm{P}-8.1 \mathrm{~K}$ fertilizer in the spring. The 2 -ft-wide VFA received $300 \mathrm{lb} /$ acre of $10 \mathrm{~N}-$ $4.4 \mathrm{P}-8.1 \mathrm{~K}$ fertilizer in the spring and again in the summer. Earlier work (Tworkoski and Glenn, 2001, 2010) documented that sod competition reduced nitrogen $(\mathrm{N})$ availability and leaf $\mathrm{N}$, so additional $\mathrm{N}$ was added to the narrow VFA treatments to compensate. Weed control used two to four applications of $2.5 \mathrm{lb} / \mathrm{gal}$ paraquat (Gramoxone Extra; Zeneca Ag Products, Wilmington, DE) annually.

Tree water requirements were based on $70 \%$ of pan evaporation (Glenn, 1995, 1999). Irrigation treatments consisted of two drip emitters per tree $(\mathrm{l} \mathrm{gal} / \mathrm{h})$ which provided the daily water needs for the 5 -ft tree spacing and four drip emitters per tree for the $15-\mathrm{ft}$ tree spacing. Irrigation was designed and managed on a system basis rather than a single-tree basis to provide irrigation to meet the evaporative demand.

Pruning time data were collected in dormant seasons from 2000 to 2005. Data are expressed on a singletree basis. Pruning weight data were also collected in 2003 and 2004 .

Leaf samples were collected in July for leaf $\mathrm{N}$ analysis to ensure that fertilization maintained leaf $\mathrm{N}$ levels not less than $2.8 \%$ which is recognized as being necessary for adequate tree growth and productivity (Crassweller and Schupp, 2010).

In all years fruit were graded into three categories by diameter: 1) fruit $<$ $2 \frac{1}{2}$ inches, 2) $2^{3} / 4$ inches $>$ fruit $>21 / 2$ inches, and 3 ) fruit $>23 / 4$ inches. Data are expressed on a single-tree basis.

When fruit were harvested (two trees per plot), a subsample of 20 fruit per plot were randomly collected for color analysis for 2001, 2002, 2003, and 2005. Hue angle was calculated from measurements on four sides of each fruit with a colorimeter (Chroma Meter 400; Minolta, Osaka, Japan).

Trunk cross-sectional area [TCSA (square inches)] was measured in all years except 2004. Measurements were made $\mathrm{l} \mathrm{ft}$ above the soil.

Hue angle and pruning time were analyzed in a randomized complete block design of the eight production systems with six replications using repeated measures analysis. Tree diameter was analyzed using regression analysis over years with SAS (version 8; SAS Institute, Cary, NC).

Fruit weight was analyzed using analysis of covariance overall years using SAS with fruit number as the independent covariate. Dormant season pruning time in 2003 and 2004 were analyzed using analysis of covariance using SAS with pruning weight as the independent covariate. Adjusted treatment means of the eight production systems were compared using PDIFF, which compares least squares means from the analysis of covariance. Harvest year was not a significant factor in the analysis of covariance.

Cumulative pruning time was calculated using the measured pruning time for 2001 to 2005 and the pruning time in 2005 was used for 2006 and 2007 estimates. Pruning time in 2005 was significantly correlated $(P>$ 0.01 ) with pruning time in 2003 and 2004 by simple correlation using Kendall correlation and by rank correlation using Pearson correlation (data not presented) in SAS. Pruning time per acre was the product of tree pruning time $\times$ tree density. Economic analysis assumed: 1) \$12/h labor cost for pruning, 2) $\$ 5 /$ tree for planting costs, 3 ) $\$ 0.52 / \mathrm{lb}$ for fruit $>23 / 4$ inches, 4 ) $\$ 0.38 / \mathrm{lb}$ for $2^{3} / 4$ inches $>$ fruit $>21 / 2$ inches, and 5) $\$ 0.29 / \mathrm{lb}$ for fruit $<2^{1 / 2}$ inches based on the average price for fresh market peaches in 2007 (National Peach Council, 2007). Cumulative pruning time, cumulative total fruit weight, cumulative total fruit weight $>23 / 4$ inches, and net present value (NPV) of the eight peach production systems were analyzed using regression analysis over years with SAS. The discount rate was $5 \%$.

\section{Results and discussion}

The objectives of the study were to evaluate the interactions of pruning

Table 1. Peach production system treatments in Kearneysville, WV, in 1999-2007.

\begin{tabular}{lcccccccc}
\hline System component & System 1 & System 2 & System 3 & System 4 & System 5 & System 6 & System 7 & System 8 \\
\hline Cultivar or selection & Loring & Loring & Loring & Loring & Loring & Loring & KV930465 & KV930465 \\
Tree ht $(\mathrm{ft})^{y}$ & 8 & 8 & 8 & 8 & 8 & 8 & 12 \\
In-row tree spacing $(\mathrm{ft})$ & 15 & 5 & 5 & 15 & 5 & 5 & 5
\end{tabular}

Pruning system Open center Central leader Y shaped Open center Central leader Y shaped Multiple leader Multiple leader

$\begin{array}{lllllllll}\text { Vegetation-free area }(\mathrm{ft}) & 8 & 8 & 8 & 2 & 2 & 2 & 8 & 2\end{array}$

${ }^{\mathrm{z}} \mathrm{KV} 930465$ is a selection with the pillar growth form.

${ }^{\mathrm{y}} 1 \mathrm{ft}=0.3048 \mathrm{~m}$. 


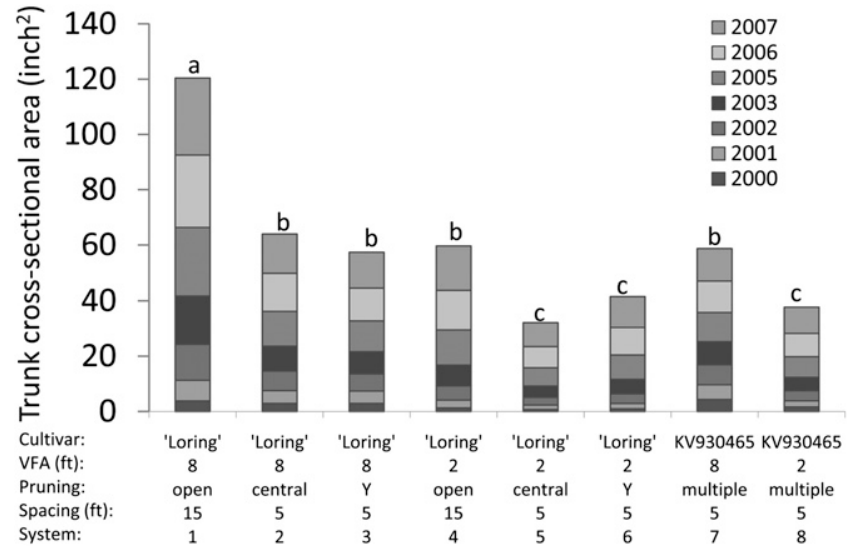

Fig. 1. Effect of cultivar or selection (KV930465 is a selection with the pillar growth form), vegetation-free area (VFA), pruning system (open center, central leader, and multiple leader), and tree spacing in eight peach production systems (see Table 1) on peach tree trunk cross-sectional area in 7 years at Kearneysville, WV. Mean separation is based on regression analysis over 7 years $(P \geq 0.05)$. No data were collected in $2004 ; 1 \mathrm{ft}=0.3048 \mathrm{~m}, 1$ inch $^{2}=6.4516 \mathrm{~cm}^{2}$.

Table 2. Effect of cultivar/selection (KV930465 is a selection with the pillar growth form), vegetation-free area (VFA), tree spacing, and pruning in eight peach production systems on peach average fruit weight and weight of fruit $>2.75$ inches $(6.985 \mathrm{~cm})$ diameter for 7 years at Kearneysville, WV.

\begin{tabular}{|c|c|c|c|c|c|c|}
\hline \multirow{2}{*}{$\begin{array}{l}\text { Cultivar or } \\
\text { selection }\end{array}$} & \multirow{2}{*}{$\begin{array}{c}\text { VFA } \\
\text { width }(\mathrm{ft})^{\mathrm{z}}\end{array}$} & \multirow{2}{*}{$\begin{array}{c}\text { Tree } \\
\text { spacing }(\mathrm{ft})\end{array}$} & \multirow{2}{*}{$\begin{array}{l}\text { Pruning } \\
\text { system }^{\mathrm{y}}\end{array}$} & \multirow{2}{*}{$\begin{array}{c}\text { System } \\
\text { code }^{\mathrm{x}}\end{array}$} & \multicolumn{2}{|r|}{ Fruit wt $(g)^{z}$} \\
\hline & & & & & Avg & $>2.75$ inches diam \\
\hline Loring & 8 & 15 & $\mathrm{OC}$ & 1 & $188 \mathrm{a}^{\mathrm{w}}$ & $210 \mathrm{a}$ \\
\hline Loring & 8 & 5 & $\mathrm{CL}$ & 2 & 177 a & $191 \mathrm{bc}$ \\
\hline Loring & 8 & 5 & $\mathrm{Y}$ & 3 & $175 \mathrm{a}$ & $190 \mathrm{bc}$ \\
\hline Loring & 2 & 15 & $\mathrm{OC}$ & 4 & $185 \mathrm{a}$ & 197 b \\
\hline Loring & 2 & 5 & $\mathrm{CL}$ & 5 & $171 \mathrm{a}$ & $181 \mathrm{c}$ \\
\hline Loring & 2 & 5 & $\mathrm{Y}$ & 6 & $176 \mathrm{a}$ & $184 \mathrm{c}$ \\
\hline KV930465 & 8 & 5 & ML & 7 & $141 \mathrm{~b}$ & $173 \mathrm{~cd}$ \\
\hline KV930465 & 2 & 5 & ML & 8 & $145 \mathrm{~b}$ & $164 \mathrm{~d}$ \\
\hline
\end{tabular}

${ }^{\mathrm{z}} 1 \mathrm{ft}=0.3048 \mathrm{~m}, 1 \mathrm{~g}=0.0353 \mathrm{oz}$.

${ }^{y} \mathrm{OC}=$ open center, $\mathrm{CL}=$ minimal pruning central leader, $\mathrm{Y}=\mathrm{Y}$-shaped pruning, $\mathrm{ML}=$ multiple leader.

'See Table 1 for system description.

"Indicates significant difference within a year $(P \geq 0.05)$ based on analysis of variance. Mean separation is based on the Ryan-Einot-Gabriel-Welsch multiple range test. strategies, groundcover management, tree densities, and peach architecture combined in eight peach production systems on components of yield and economic value. Since the basis of comparison is the system, it is not always valid to compare system components. In designing the systems, irrigation was based on system need and two pragmatic decisions were made: First, there would be no summer pruning in any of the systems since summer pruning was most effective at low density rather than high density (Miller and Scorza, 2010). We recognized a negative bias in doing this for the 15-ft-spaced systems, but summer pruning is not always a part of the low-density peach production practices. Second, because of the upright nature of the pillar peach it would be a negative bias to maintain the tree at $8 \mathrm{ft}$ when previous work supported a 12 - $\mathrm{ft}$ tree height to use the genetic potential of the tree type (Miller and Scorza, 2010).

TCSA was greatest for System 1 (Fig. 1). Systems 2, 3, 4, and 7 had intermediate TCSA and Systems 5, 6, and 8 had the smallest TCSA. Planting trees in the 2-ft VFA significantly reduced the TCSA compared with the 8 -ft VFA for the four-tree spacing, pruning combinations, and cultivars (Systems 1, 2, 3, 7 vs. 4, 5, 6, 8).

Average total fruit weight adjusted for crop load was greatest for all the systems with 'Loring' and least with the pillar systems (Table 2). The size of the VFA or pruning system did not affect average fruit weight for either cultivar. The lack of differences in average fruit weight for each cultivar

Table 3. Effect of cultivar/selection (KV930465 is a selection with the pillar growth form), vegetation-free area (VFA), tree spacing, and pruning in eight peach production systems on fruit hue angle (degrees) in 4 years at Kearneysville, WV.

\begin{tabular}{|c|c|c|c|c|c|c|c|c|}
\hline \multirow{2}{*}{$\begin{array}{l}\text { Cultivar or } \\
\text { selection }\end{array}$} & \multirow{2}{*}{$\begin{array}{c}\text { VFA } \\
\text { width }(\mathrm{ft})^{\mathrm{z}}\end{array}$} & \multirow{2}{*}{$\begin{array}{c}\text { Tree } \\
\text { spacing }(\mathrm{ft})\end{array}$} & \multirow{2}{*}{$\begin{array}{l}\text { Pruning } \\
\text { system }^{y}\end{array}$} & \multirow{2}{*}{$\begin{array}{l}\text { System } \\
\text { code }^{x}\end{array}$} & \multicolumn{4}{|c|}{ Hue angle (smaller values indicate increased red color) } \\
\hline & & & & & 2001 & 2002 & 2003 & 2005 \\
\hline Loring & 8 & 15 & $\mathrm{OC}$ & 1 & $65 \mathrm{a}^{\mathrm{w}}$ & $34 \mathrm{a}$ & $43 \mathrm{~b}$ & $47 \mathrm{a}$ \\
\hline Loring & 8 & 5 & $\mathrm{Y}$ & 3 & $57 \mathrm{ab}$ & $31 \mathrm{~b}$ & $44 \mathrm{~b}$ & $49 \mathrm{a}$ \\
\hline Loring & 2 & 15 & $\mathrm{OC}$ & 4 & $62 \mathrm{ab}$ & $30 \mathrm{~b}$ & $37 \mathrm{~cd}$ & $40 \mathrm{~b}$ \\
\hline Loring & 2 & 5 & $\mathrm{CL}$ & 5 & $64 \mathrm{a}$ & $25 \mathrm{c}$ & $40 \mathrm{bc}$ & nd \\
\hline KV930465 & 2 & 5 & $\mathrm{ML}$ & 8 & $27 \mathrm{c}$ & $26 \mathrm{c}$ & $35 \mathrm{~cd}$ & $36 \mathrm{~b}$ \\
\hline
\end{tabular}

${ }^{\mathrm{z}} \mathrm{l} \mathrm{ft}=0.3048 \mathrm{~m}$.

yC $=$ open center, $\mathrm{CL}=$ minimal pruning central leader, $\mathrm{Y}=\mathrm{Y}$-shaped pruning, $\mathrm{ML}=$ multiple leader.

x See Table 1 for system description.

wIndicates significant difference within a year $(P \geq 0.05)$ based on analysis of variance. Mean separation is based on the Ryan-Einot-Gabriel-Welsch multiple range test. vo data. 
Table 4. Effect of cultivar/selection (KV930465 is a selection with the pillar growth form), vegetation-free area (VFA), tree spacing, and pruning in eight peach production systems on pruning time in 6 years at Kearneysville, WV.

\begin{tabular}{|c|c|c|c|c|c|c|c|c|c|c|}
\hline \multirow{2}{*}{$\begin{array}{l}\text { Cultivar or } \\
\text { selection }\end{array}$} & \multirow{2}{*}{$\begin{array}{c}\text { VFA } \\
\text { width }(\mathrm{ft})^{\mathrm{z}}\end{array}$} & \multirow{2}{*}{$\begin{array}{c}\text { Tree } \\
\text { spacing }(\mathrm{ft})\end{array}$} & \multirow{2}{*}{$\begin{array}{l}\text { Pruning } \\
\text { system }^{\mathrm{y}}\end{array}$} & \multirow{2}{*}{$\begin{array}{l}\text { System } \\
\text { code }^{\mathrm{x}}\end{array}$} & \multicolumn{6}{|c|}{ Pruning time ( $\mathrm{min} /$ tree) } \\
\hline & & & & & 2000 & 2001 & 2002 & 2003 & 2004 & 2005 \\
\hline Loring & 8 & 15 & $\mathrm{OC}$ & 1 & $0.73 b^{w}$ & $3.80 \mathrm{~b}$ & $9.38 \mathrm{a}$ & $7.47 \mathrm{a}$ & $6.74 \mathrm{a}$ & $12.10 \mathrm{a}$ \\
\hline Loring & 8 & 5 & $\mathrm{Y}$ & 3 & $0.78 \mathrm{~b}$ & $2.97 \mathrm{c}$ & $5.68 \mathrm{~b}$ & $4.20 \mathrm{bc}$ & $5.28 \mathrm{~b}$ & $7.44 \mathrm{ab}$ \\
\hline Loring & 2 & 15 & $\mathrm{OC}$ & 4 & $0.59 \mathrm{bc}$ & $1.37 \mathrm{~d}$ & $3.72 \mathrm{c}$ & $3.53 \mathrm{~cd}$ & $3.58 \mathrm{~cd}$ & $4.25 \mathrm{~b}$ \\
\hline Loring & 2 & 5 & CL & 5 & $0.42 \mathrm{c}$ & $0.87 \mathrm{~d}$ & $1.85 \mathrm{~d}$ & $1.80 \mathrm{e}$ & $1.86 \mathrm{e}$ & $2.37 \mathrm{~b}$ \\
\hline KV930465 & 2 & 5 & ML & 8 & $0.40 \mathrm{c}$ & $1.36 \mathrm{~d}$ & $2.10 \mathrm{~d}$ & $2.50 \mathrm{de}$ & $3.40 \mathrm{~cd}$ & $3.96 \mathrm{~b}$ \\
\hline
\end{tabular}

${ }^{\mathrm{z}} 1 \mathrm{ft}=0.3048 \mathrm{~m}$.

y $\mathrm{OC}=$ open center, $\mathrm{CL}=$ minimal pruning central leader, $\mathrm{Y}=\mathrm{Y}$-shaped pruning, $\mathrm{ML}=$ multiple leader.

'See Table 1 for system description.

"Indicates significant difference within a year $(P \geq 0.05)$ based on analysis of variance. Mean separation is based on the Ryan-Einot-Gabriel-Welsch multiple range test.

indicated that the irrigation strategy provided equivalent available water to each production system. Mean fruit weight of fruit greater than $23 / 4$ inches was greatest for System 1 followed by Systems 2, 3, and 4 (Table 2). Systems 5 and 6 had the lowest mean fruit $>$ $23 / 4$ inches diameter for the systems with 'Loring'. Pillar Systems 7 and 8 had the lowest mean fruit weight $>23 / 4$ inches. Within a pruning system, the size of the VFA did not significantly reduce fruit $>23 / 4$ inches except for 'Loring' at 15 - $\mathrm{ft}$ spacing and the OC pruning system in which the $2-\mathrm{ft}$ VFA significantly reduced mean fruit weight $>23 / 4$ inches. In this study, it does appear that irrigation and high fertilization can overcome the competitive effects of a narrow VFA on fruit size when adjusted for crop load. Tworkoski and Glenn (2001) demonstrated that sod competition reduced peach yield primarily through reduced $\mathrm{N}$ availability and uptake. Pillar trees have a smaller fruit size compared with 'Loring' at comparable tree spacing and VFA size. This is a genetic difference, not a response to cultural treatments.

Pillar Systems 7 and 8 generally had the greatest red color (Table 3 ) compared with all the 'Loring' systems. Interactions of cultivar with year and pruning system were not consistent. Fruit color development was the result of a genetic difference and not because of the cultural treatments. Fruit color in pillar Systems 7 and 8 were unaffected by VFA. The 2 -ft VFA improved red color in: a) the 'Loring' System 4 compared with System 1 in 3 of 4 years; b) System 2 compared with System 5 with CL pruning in all years; and c) System 6 compared with System 3 but in only $\mathrm{l}$ year for $\mathrm{Y}$ pruning. By reducing
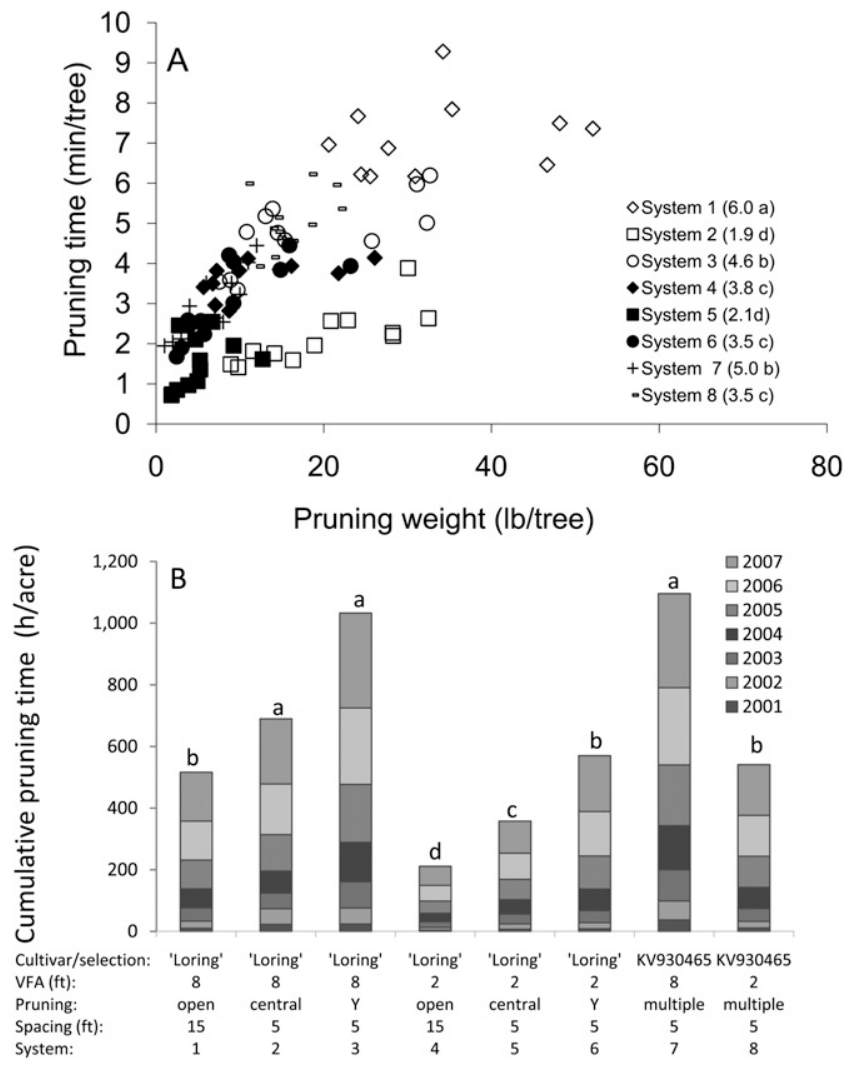

Fig. 2. Effect of cultivar or selection (KV930465 is a selection with the pillar growth form), vegetation-free area (VFA), pruning system (open center, central leader, and multiple leader), and tree spacing in eight peach production systems (see Table 1) on pruning time per tree $(A)$ and cumulative pruning time per acre $(B)$ for 7 years at Kearneysville, WV. Values in parentheses for (A) are the adjusted mean time values and mean separation using analysis of covariance with pruning weight per tree as the independent covariate $(P \geq 0.05)$. Treatment separation for $(B)$ is based on regression analysis over 7 years $(P \geq 0.05) ; 1 \mathrm{lb}=0.4536 \mathrm{~kg}, 1 \mathrm{~h} / \mathrm{acre}=2.4711$ h.ha ${ }^{-1}$.

growth with the 2-ft VFA (Fig. 1), light penetration was likely improved resulting in improved color development and this effect was most consistent with the CL system that had minimal pruning compared with the more intensively managed $\mathrm{Y}$-shaped system.
Pruning time per tree generally increased from 2001 to 2005 (Table 4). In 2003 and 2004, some treatments had reduced pruning time per tree because of the adjustments in the pruning strategy. In 2 of the 6 years, the 2 -ft VFA reduced pruning time 
per tree for all treatments compared with the 8 -ft VFA (Table 4). In 5 of 6 years, the 2 -ft VFA reduced pruning time per tree of 'Loring' Systems 1 vs. 4 and the pillar Systems 7 vs. 8. In 4 of 6 years, the 2 -ft VFA reduced pruning time per tree of the 'Loring' Systems 2 vs. 5 and 3 vs. 6. Minimal CL pruning reduced pruning time per tree compared with $\mathrm{Y}$-shaped pruning in only 1 of 6 years over both VFA sizes. Miller and Scorza (2010) demonstrated that dormant pruning time of pillar trees was $84 \%$ of a standard architecture tree when spaced $5 \mathrm{ft}$, on a per tree basis. In the 8-ft VFA, comparable to Miller and Scorza (2010), pillar System 7 required significantly greater pruning time per tree in the first 2 years of establishment and required significantly greater pruning time per tree than the 'Loring' Systems 2 and 3 , and in 1 year of the remaining 4 years of the study. The increased pruning time was due primarily to the need to use pole pruners and the difficulty in making thinning cuts on the very upright branches of the pillar tree.

The efficiency of pruning time per tree was least for 'Loring' System 1 resulting in $6 \mathrm{~min}$ of pruning to remove the mean value of pruning weight for the study (15.4 lb per tree) (Fig. 2A). The minimally pruned CL system in 'Loring' Systems 2 and 5 required the least amount of time per tree to remove the mean value of pruning weight for either VFA size because only large diameter branches were removed. The 2 - $\mathrm{ft}$ VFA reduced the pruning time to remove the mean value of pruning weight from the pillar system and the Y-shaped 'Loring' system compared with the 8 -ft VFA. Figure $2 A$ provides information on how much wood is removed for a unit of pruning time. For example, to remove $15.4 \mathrm{lb}$ of wood requires 6 min of pruning time in System 1 but only $1.9 \mathrm{~min}$ in System 2 (Fig. 2A), therefore System 2 is more efficient.

When pruning time per tree is converted into pruning time per acre and adjusted for tree density (Fig. $2 \mathrm{~B})$, the pruning time is greatest for Systems 2, 3, and 7. Systems 1, 6, and 8 are intermediate but greater than System 5. System 4 had the least pruning time per acre. Reducing the VFA from 8 to $2 \mathrm{ft}$ significantly reduced pruning time in all systems. Within the 'Loring' systems: a) the Y-pruning system had significantly greater pruning times with a 2 -ft VFA and numerically greater pruning time with the 8 -ft VFA; b) the OC pruning system had the least pruning time in either VFA; and c) the minimally pruned CL system was intermediate in either VFA. The 2-ft VFA significantly reduced pruning time of the pillar systems (7 vs. 8).

Cumulative yield, total fruit count, and yield of fruit $>23 / 4$ inches (Fig. 3) were greatest for Systems 2, 3 , and 7. Systems 1, 2, and 8 were intermediate but greater than System 5. System 4 had the least cumulative yield, total fruit count, and yield of fruit $>23 / 4$ inches. Although overall fruit size for a given cultivar was not reduced by the 2 - $\mathrm{ft}$ VFA (Table 2) when adjusted for crop load, crop load was reduced by the 2 - $\mathrm{ft}$ VFA because of reduced shoot growth and fruit bud formation in all systems and in all years.

The NPV indicated, for the economic values used, that all systems using the 5 -ft spacing and 8 -ft VFAs had the greatest return (Fig. 3). System 2 had the second highest return. Systems 6 and 8 had the third highest returns. System 4 had the lowest economic return and System 5 was intermediate between System 4 and Systems 6 and 8. The economic analysis indicates that high-density peach production can be economically viable compared with the traditional system (System 1), and the pillar peach can contribute to the development of high-density systems. For the tree densities of the current study, the use of sod management did not appear to offer an economic basis to reduce pruning costs because of the loss of yield potential that is greater than the labor cost savings. However, the pillar trees did not fill the allotted space in the orchard and it is likely that higher densities of pillar trees could provide an economic benefit. We were disappointed that the trees did not fill the space and designed the study with the expectation of full coverage.

In conclusion, high-density peach production $(5 \times 18 \mathrm{ft})$ and 8 - $\mathrm{ft}$ VFA with either standard ('Loring') or pillar cultivars demonstrated significant horticultural and economic benefit compared with the traditional system

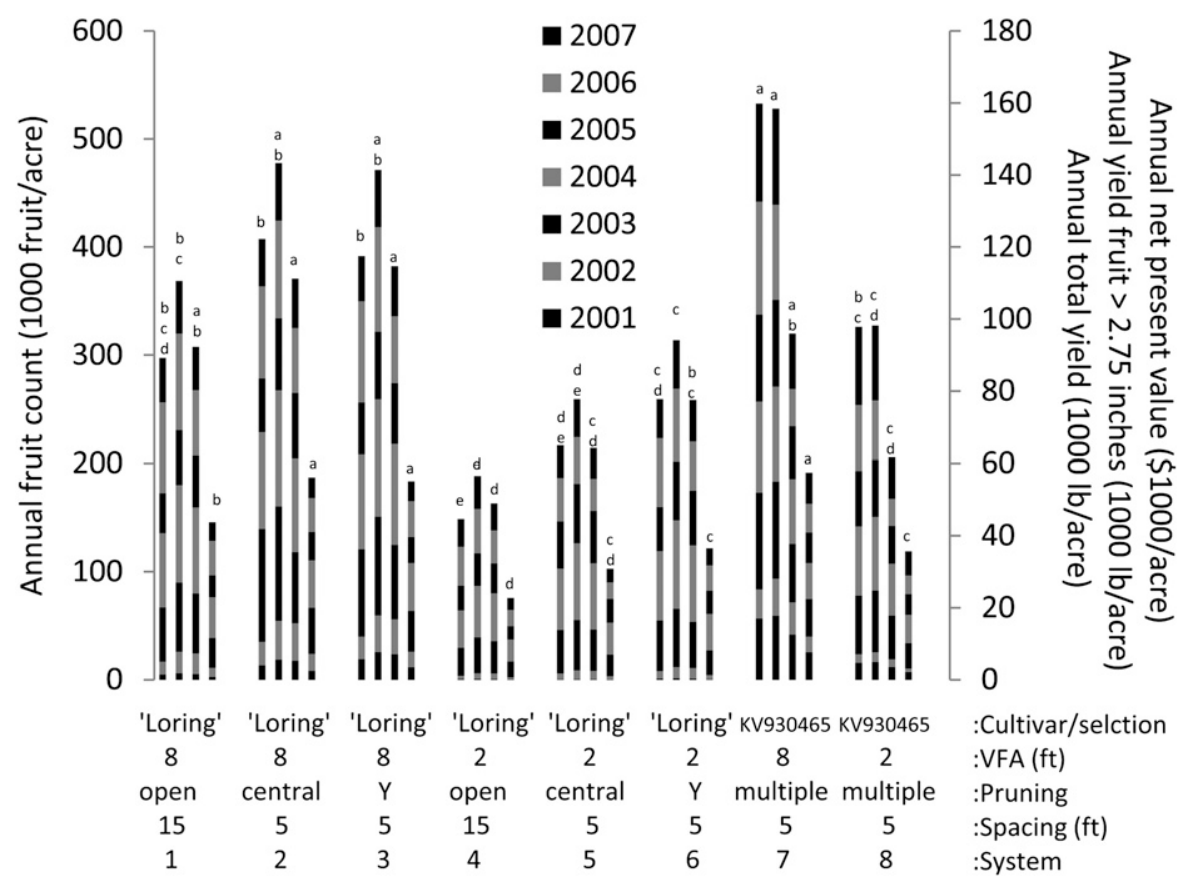

Fig. 3. Effect of cultivar or selection (KV930465 is a selection with the pillar growth form), vegetation-free area (VFA), pruning system (open center, central leader, and multiple leader), and tree spacing in eight peach production systems (see Table 1 ) on (from left to right) annual fruit count and total yield, total fruit weight of fruit $>2.75$ inches $(6.985 \mathrm{~cm})$ diameter, and net present value per acre for 7 years at Kearneysville, WV. Letters above the bar are mean separation of the cumulative values in 2007 , based on the Ryan-Einot-Gabriel-Welsch multiple range test $(P \geq$ 0.05 ) from the analysis of variance; $1 \mathrm{ft}=0.3048 \mathrm{~m}, 1$ fruit $/$ acre $=2.4711$ fruit $/ \mathrm{ha}$, $\$ 1.00 /$ acre $=\$ 2.4711 / \mathrm{ha}, 1 \mathrm{lb} /$ acre $=1.1209 \mathrm{~kg} \cdot \mathrm{ha}^{-1}$. 
(System 1). The use of sod management did reduce pruning time and costs but the reduction of crop load reduced net return. Future development of high-density peach production should address further reductions of pruning costs in pillar peach types that might be attained by increasing density and pruning trees to maintain an 8 -ft tree height instead of tree heights $>8 \mathrm{ft}$. Miller and Scorza (2010) found that reducing the height of a pillar-type peach did not have as dramatic an effect as expected, and increasing tree density may overcome the loss of crop-bearing shoots as well as reduce pruning time by eliminating pole pruning of pillar types. Development of pillar peach types with larger fruit size will also increase the NPV of the high-density system.

\section{Literature cited}

Bassi, D., A. Dima, and R. Scorza. 1994. Tree structure and pruning response of six peach growth forms. J. Amer. Soc. Hort. Sci. 119:378-382.

Boland, A.M., P.D. Mitchell, I. Goodwin, and P.H. Jerie. 1994. The effect of soil volume on young peach tree growth and water use. J. Amer. Soc. Hort. Sci. 119: 1157-1162.

Chalmers, D.J., P.D. Mitchell, and L. van Heek. 1981. Control of peach tree growth and productivity by regulated water supply, tree density, and summer pruning. J. Amer. Soc. Hort. Sci. 106:307-312.
Crassweller, R.M. and J.R. Schupp. 2010. Plant nutrition, p. 10-16. In: R. Crassweller (ed.). Pennsylvania tree fruit production guide. Pennsylvania State Univ., University Park.

Glenn, D.M. 1995. Irrigation scheduling, p. 161-168. In: H.W. Hogmire (ed.). Mid-Atlantic orchard monitoring guide. Northeast Reg. Agr. Eng. Serv., Ithaca, NY.

Glenn, D.M. 1999. Analysis of trickle and pulse microsprinkler irrigation of processing apples. J. Tree Fruit Production 2:11-17.

Glenn, D.M. and M.J. Newell. 2008. Long-term effects of sod competition on peach yield. HortTechnology 18:445-448.

Glenn, D.M. and W.V. Welker. 1996. Sod competition in peach production: II. Establishment beneath mature trees. J. Amer. Soc. Hort. Sci. 121:670-675.

Glenn, D.M., W.V. Welker, and G.M. Greene. 1996. Sod competition in peach production: I. Managing sod proximity. J. Amer. Soc. Hort. Sci. 121:666-669.

Grossman, Y.L. and T.M. DeJong. 1998. Training and pruning system effects on vegetative growth potential, light interception, and cropping efficiency in peach trees. J. Amer. Soc. Hort. Sci. 123:1058-1064.

Miller, S. and R. Scorza. 2002. Training and performance of pillar, upright, and standard form peach trees - Early results. Acta Hort. 592:391-399.

Miller, S. and R. Scorza. 2010. Response of two novel peach tree growth habits to in-row tree spacing, training system, and pruning: Effect on growth and pruning. J. Amer. Pomol. Soc. 64:199-217.
Naor, A. 2006. Irrigation scheduling of peach-deficit irrigation at different phenological stages and water stress assessment. Acta Hort. 713:339-350.

National Peach Council. 2007. 2007 Peach statistical yearbook. National Peach Council, Columbia, SC.

Ran, Y., B. Bar-Yosef, and A. Erez. 1992. Root volume influence on dry matter production and partitioning as related to nitrogen and water uptake rates by peach. J. Plant Nutr. 15:713-726.

Scorza, R. 1984. Characterization of four distinct peach tree growth types. J. Amer. Soc. Hort. Sci. 109:455-457.

Scorza, R. 1988. Progress in the development of new peach tree growth habits. Compact Fruit Tree 21:92-98.

Scorza, R. 2004. Peach tree named 'Crimson Rocket.' U.S. Plant Patent 15,216 P2. U.S. Patent and Trademark Office, Washington, DC.

Scorza, R., S. Miller, D.M. Glenn, W.R. Okie, and T. Tworkoski. 2006. Developing peach cultivars with novel growth habits. Acta Hort. 713:61-64.

Tworkoski, T.J. and D.M. Glenn. 2001. Yield, shoot and root growth, and physiological responses of mature peach trees to grass competition. HortScience 36: 1214-1218.

Tworkoski, T.J. and D.M. Glenn. 2010. Long-term effects of managed grass competition and two pruning methods on growth and yield of peach trees. Sci. Hort. 126:130-137. 